\title{
VENTROSIA MARITIMA (MILASCHEWITSCH, 1916) AND V. VENTROSA (MONTAGU, 1803) IN GREECE: MOLECULAR DATA AS A SOURCE OF INFORMATION ABOUT SPECIES RANGES WITHIN THE HYDROBIINAE (CAENOGASTROPODA: TRUNCATELLOIDEA)
}

\author{
MAGDALENA SZAROWSKA, ANDRZEJ FALNIOWSKI
}

\begin{abstract}
Department of Malacology, Institute of Zoology, Jagiellonian University, Gronostajowa 9, 30-387 Cracow, Poland (e-mail: andrzej.falniowski@uj.edu.pl)

ABSTRACT: Using molecular data (DNA sequences of mitochondrial COI and nuclear ribosomal 18SrRNA genes), we describe the occurrence of two species of Ventrosia Radoman, 1977: V. ventrosa (Montagu, 1803) and V. maritima (Milaschewitsch, 1916) in Greece. These species are found at two disjunct localities: $V$. ventrosa at the west coast of Peloponnese (Ionian Sea) and V. maritima on Milos Island in the Cyclades (Aegean Sea). Our findings expand the known ranges of both species: we provide the first molecularly confirmed record of $V$. ventrosa in Greece, and extend the range of the presumably Pontic $V$. maritima nearly $500 \mathrm{~km}$ SSW into the Aegean Sea. Our data confirm the species distinctness of V. maritima.
\end{abstract}

KEY WORDS: Truncatelloidea, COI, 18S rRNA, shell, Ventrosia, species distinctness, species range

\section{INTRODUCTION}

Data on the Greek Hydrobiinae, inhabiting brackish waters, are less than scarce. SCHÜTT (1980) did not list any species belonging to this subfamily in his monograph on the Greek Hydrobiidae. Although MuUs $(1963,1967)$ demonstrated that the morphology of the penis and the head pigmentation must be studied to determine a species, since the shell characters are too variable, many hydrobiologists and marine biologists report records of those species determined with the shell characters alone (e.g. Koutsoubas et al. 2000, EVAGELOPOULOS et al. 2009). In fact, the differences shown by MUUS (1963, 1967), and confirmed by FALNIOWSKI (1986, 1987, 1988), are good enough to distinguish between the genera: Hydrobia Hartmann, 1821, Peringia Paladilhe, 1874, and Ventrosia Radoman, 1977, since morphostatic evolution, as defined by DAVIS (1992), is characteristic of the group. Non-adaptive radiation marked by the rapid proliferation of species without ecological differentiation (GITTENBERGER 1991) results in a flock of species that are not differentiated morphologically or ecologically. Thus, at a species level in the Hydrobiinae, molecular characters are inevitably necessary to distinguish a taxon (e.g. WILKE \& DAVIS 2000, WILKE \& FALNIOWSKI 2001, WILKE \& PFENNIGER 2002). Recently, KeVREKIDIS et al. (2005) reported a Pontic species Ventrosia maritima described by MilasCHEWITSCH (1916) from the Evros Delta lagoons at the border of Greece and Turkey, East Aegean Sea. Recently, Ventrosia Radoman, 1977 is often considered a junior synonym of Ecrobia Stimpson, 1865; however, in our opinion, the question remains open as long, as the identity of the North American Ecrobia truncata (Vanatta, 1924) with European Ventrosia ventrosa (or, at least, that they are congeners) is not confirmed.

The present paper reports the occurrence of two species of Ventrosia in Greece, identified using molecular data. 


\section{MATERIAL AND METHODS}

The material was collected with a sieve and found at two localities in Greece:

(1) Ahivadolimni at Milos Island, Cyclades, Aegean Sea (Fig. 1), a saline lagoon, 36² '1 17'N, 24²6'37'E, with no continuous contact with the sea, during the hot season in the form of several small, isolated water bodies, with rich submerged macrophyte vegetation (Fig. 2), and numerous snails on its bottom (Fig. 3). This is the locality described by PANTAZIDOU et al. (2006) in their paper on the euendolithic shell-boring cyanobacteria and chlorophytes; the authors reported the occurrence of Hydrobia acuta (Draparnaud, 1805) in this habitat.

(2) A big brackish lake West of Kato Xirokhórion (Fig. 1), South of Argos, close to the West coast of Peloponnese (Peloponnisos), Ionian Sea, $37^{\circ} 30^{\prime} 30^{\prime \prime} \mathrm{N}, 21^{\circ} 36^{\prime} 52^{\prime \prime} \mathrm{E}$, with rich vegetation of semi-submerged macrophytes.

Snails were washed twice in $80 \%$ ethanol and left to stand in it for around 12 hours. The ethanol was changed twice more within 24 hours and finally, after a few days, the $80 \%$ solution was replaced with a $96 \%$ one, in which the samples were stored at $-20^{\circ} \mathrm{C}$. The shells were photographed with a CANON EOS $50 \mathrm{D}$ digital camera.

DNA was extracted from foot tissue. The tissue was hydrated in TE buffer $(3 \times 10 \mathrm{~min}$.$) ; then total$ genomic DNA was extracted with the SHERLOCK extracting kit (A\&A Biotechnology), and the final product was dissolved in $20 \mu \mathrm{l}$ TE buffer. The PCR reaction was performed with the following primers: LCO1490 (5'-GGTCAACAAATCATAAAGAT ATTGG-3') (FOLMER et al. 1994) and COR722b (5'-TAAACTTCAGGGTGACCAAAAAATYA-3')
(WILKE \& DAVIS 2000) for the cytochrome oxidase subunit I (COI) mitochondrial gene and SWAM18SF1 (5'-GAATGGCTCATTAAATCAGTCGAGGTTCCT TAGATGATCCAAATC-3'), and SWAM18SR1 (5'ATCCTCGTTAAAGGGTTTAAAGTGTACTCATTCC AATTACGGAGC-3') for the 18S ribosomal RNA nuclear gene (PALUMBI 1996). The PCR conditions were as follows: COI - initial denaturation step of 4 min at $94^{\circ} \mathrm{C}$, followed by 35 cycles of $1 \mathrm{~min}$ at $94^{\circ} \mathrm{C}$, $1 \mathrm{~min}$ at $55^{\circ} \mathrm{C} 2 \mathrm{~min}$ at $72^{\circ} \mathrm{C}$, and a final extension of $4 \mathrm{~min}$ at $72^{\circ} \mathrm{C} ; 18 \mathrm{~S}$ - initial denaturation step of $4 \mathrm{~min}$ at $94^{\circ} \mathrm{C}$, followed by 40 cycles of $45 \mathrm{~s}$ at $94^{\circ} \mathrm{C}$, $45 \mathrm{~s}$ at $51^{\circ} \mathrm{C}, 2 \mathrm{~min}$ at $72^{\circ} \mathrm{C}$ and, after all cycles were completed, an additional elongation step of $4 \mathrm{~min}$ at $72^{\circ} \mathrm{C}$ was performed. The total volume of each PCR reaction mixture was $50 \mu \mathrm{l}$. To check the quality of the PCR products $10 \mu \mathrm{l}$ of the PCR product was ran on $1 \%$ agarose gel. The PCR products were purified using Clean-Up columns (A\&A Biotechnology) and were then sequenced in both directions (HILLIS et al. 1996) using BigDye Terminator v3.1 (Applied Biosystems), following the manufacturer's protocol and with the primers described above. The sequencing reaction products were purified using ExTerminator Columns (A\&A Biotechnology); DNA sequences then underwent electrophoresis on an ABI Prism sequencer. Four sequences of $18 \mathrm{~S}$, and eight of COI, were deposited in GenBank (Accession numbers: KJ406193-KJ406204). We also used the following COI sequences from GenBank: AY616139 for Ventrosia maritima (KEVREKIDIS et al. 2005), AF253077 for $V$. pontieuxini Radoman, 1973 (DAVIS et al. 1998), and AF118357 for $V$. ventrosa (Montagu, 1803) (WILKE \& DAVIS 2000).

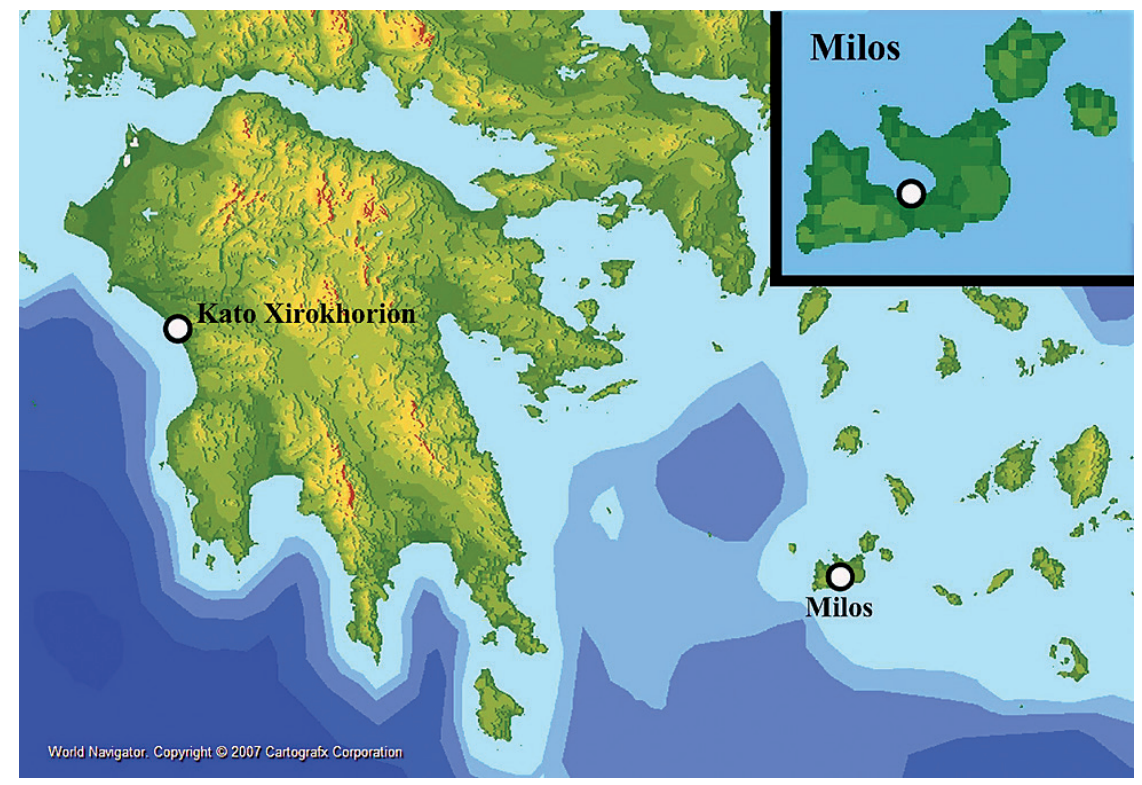

Fig. 1. Studied localities 


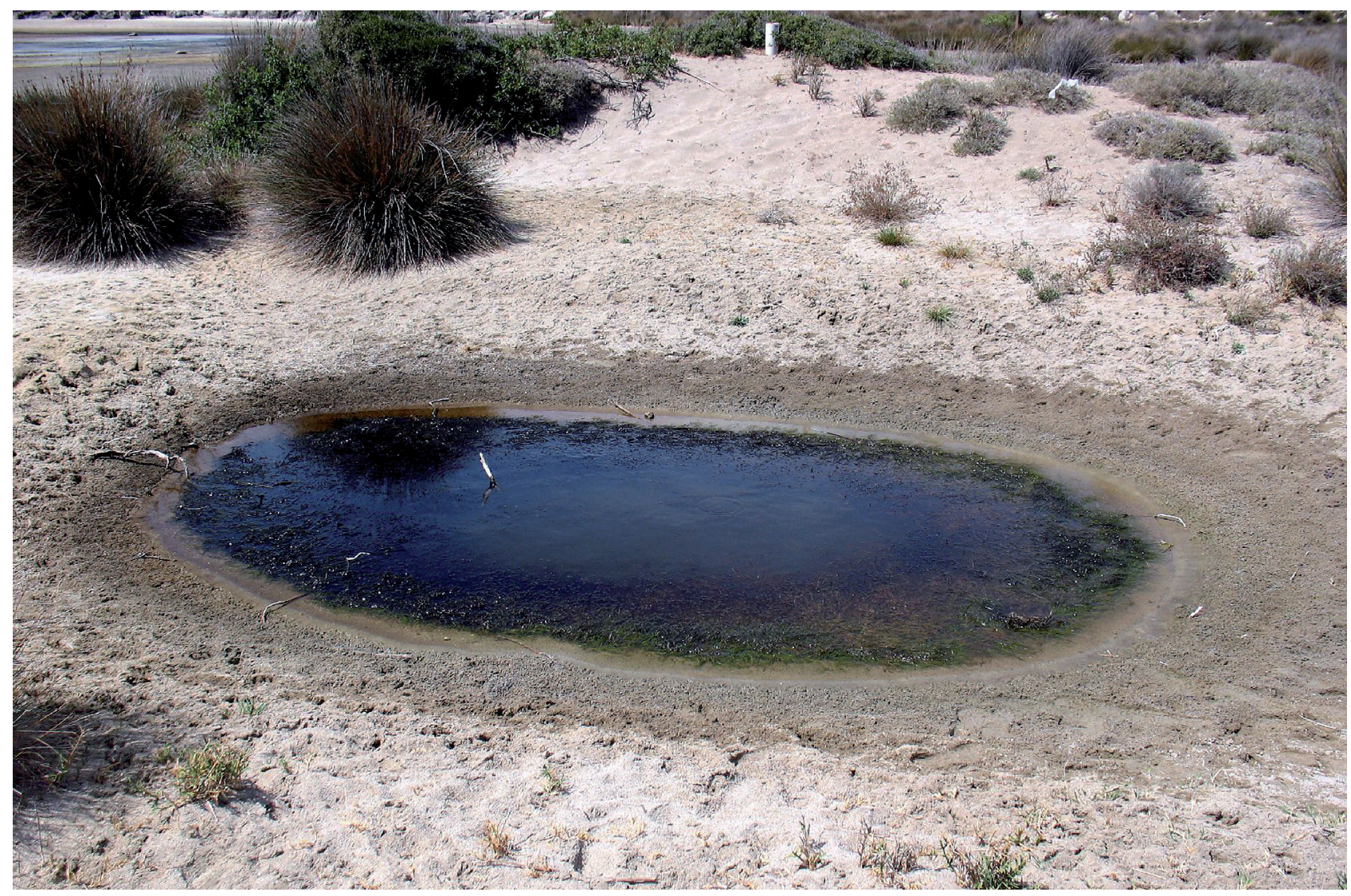

Fig. 2. Ahivadolimni at Milos Island, one of the small ponds inhabited by Ventrosia maritima during dry season

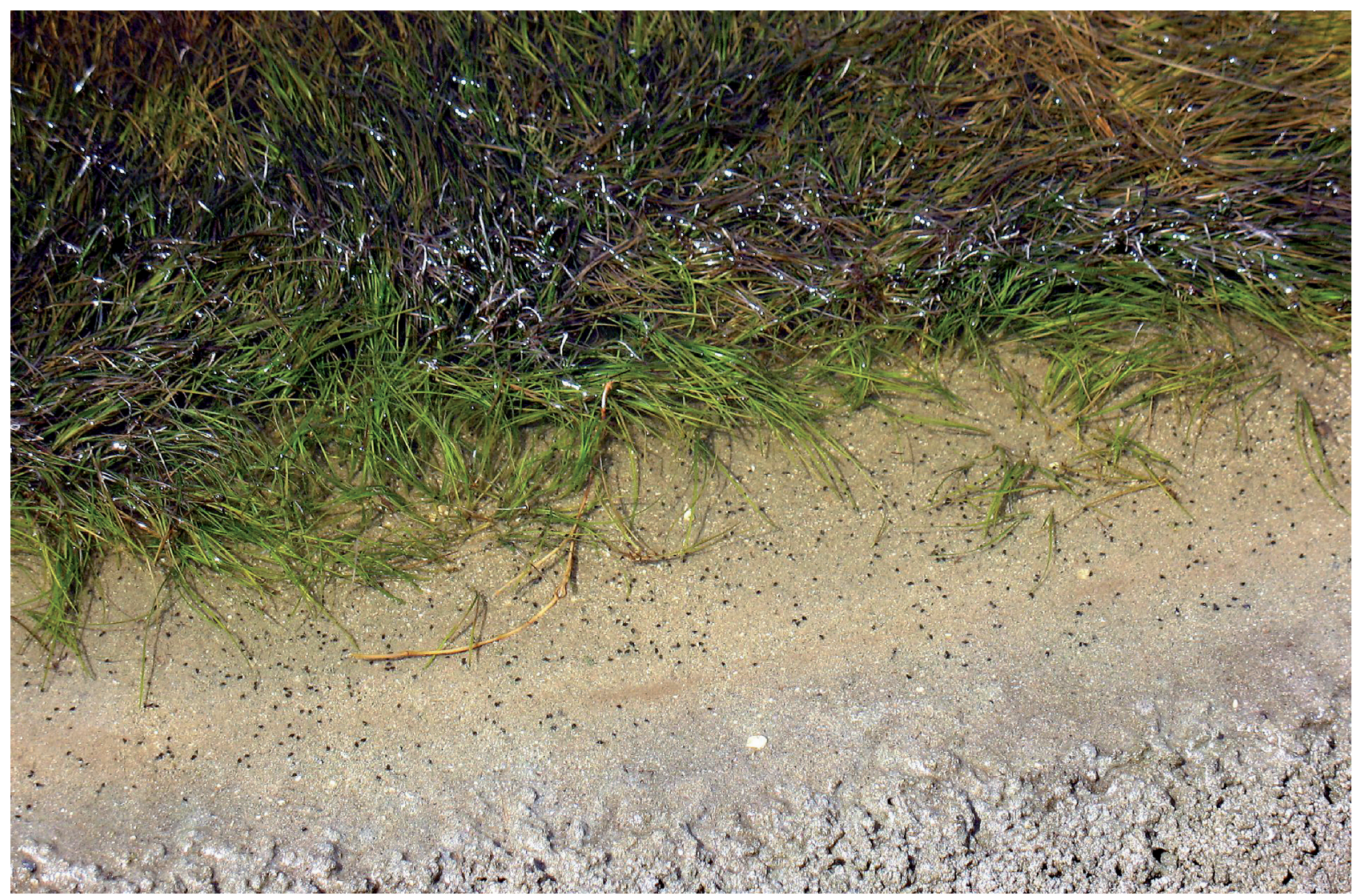

Fig. 3. A fragment of Fig. 2, snails visible as black points on the sand 
The sequences were aligned by eye using BioEdit 5.0.0 (HALL 1999). MEGA5.10 (TAMURA et al. 2011) was applied to infer p-distances and phylogenetic relationships between the sequences, applying maximum likelihood technique. Nodal support was estimated using the bootstrap (BS) approach
(FELSENSTEIN 1985). Bootstrap values for ML trees were calculated using 10,000 bootstrap replicates, with MEGA5.10 and the same model parameters $(\mathrm{HKY}+\Gamma$ : Hasegawa, Kishino and Yano with $\Gamma$ distribution) as for ML analysis.

\section{RESULTS}

Shells of the Hydrobiinae from the Ahivadolimni lagoon on Milos are presented in Figs 4-10, and those from the brackish lake West of Kato Xirokhórion on Peloponnese are shown in Figs 11-18. Both male and female reproductive organs were typical of Ventrosia and showing no differences between $V$. maritima and $V$. ventrosa. Four sequences of $18 \mathrm{~S}$, two for each locality (GenBank Accession numbers: KJ406193-KJ406196), were identical, and only in two nucleotides differ from $V$. ventrosa from GenBank (AF367681: WILKE et al. 2001). Eight COI sequences (GenBank Accession numbers: KJ406197-KJ406204), four for each locality, were analysed. Pairwise p-distances (Table 1) were lower in the population from Milos (mean p-distance $=0.001)$ than in the population from Peloponnese (mean p-distance $=0.009$ ). . Mean p-distance in the group consisting of the Milos specimens and the ones from the GenBank: V. maritima from the Evros, Aegean Sea was 0.003, and, including the one of " $B$. pontieuxini" from the Black Sea was 0.006; in the group

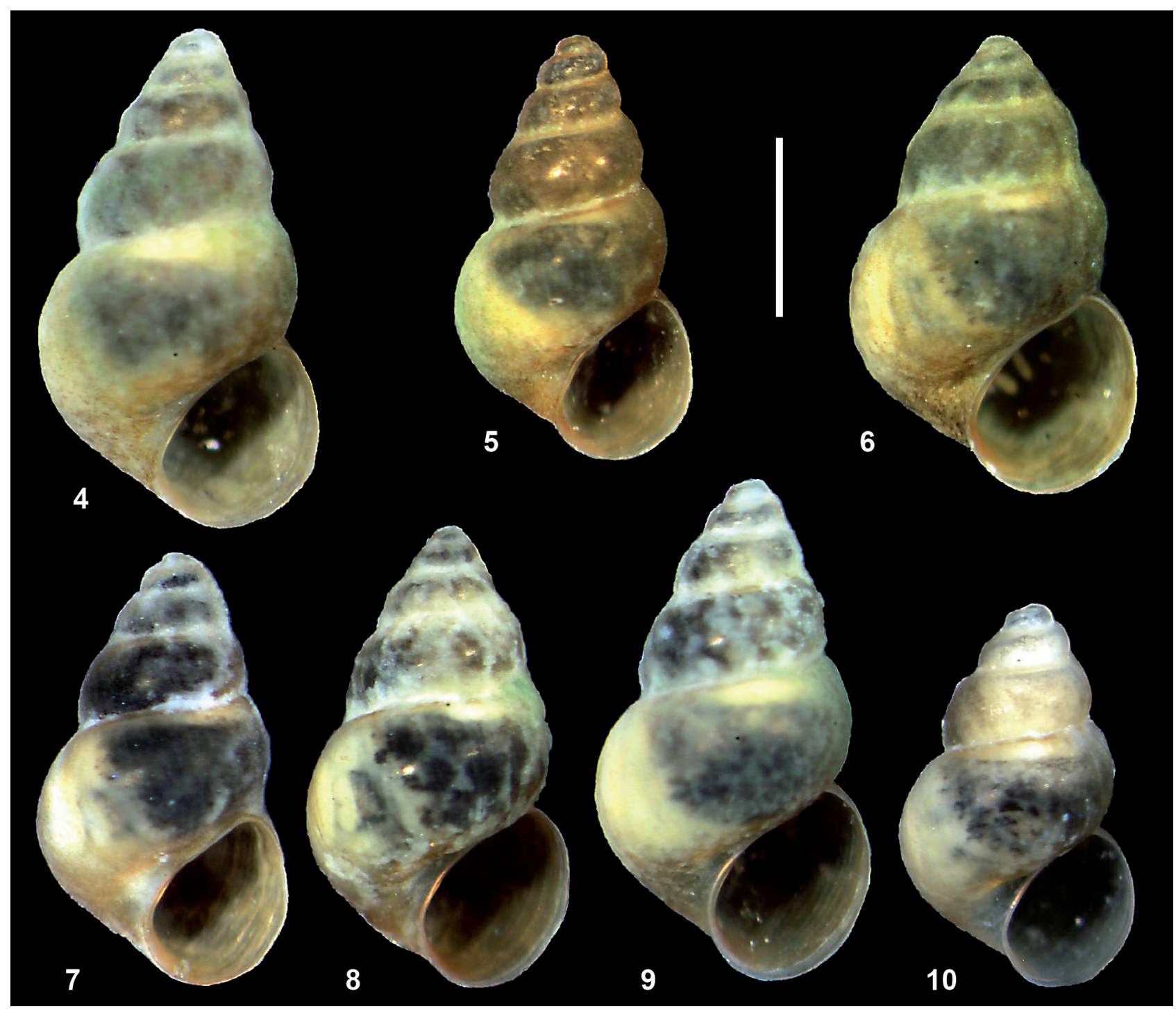

Figs 4-10. Shells of Ventrosia maritima from Ahivadolimni, scale bar equals $1 \mathrm{~mm}$ 


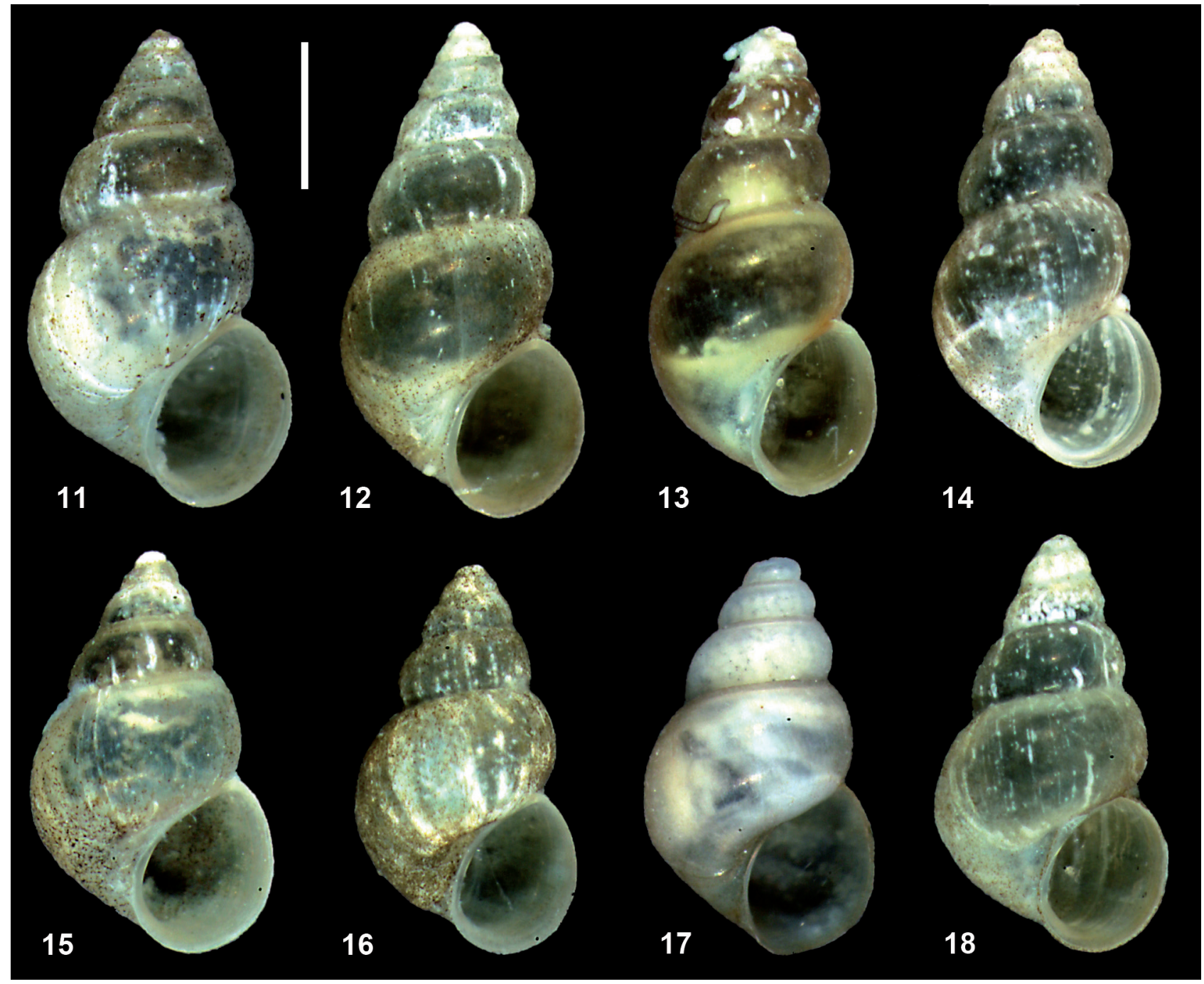

Figs 11-18. Shells of Ventrosia ventrosa from brackish lake West of Kato Xirokhórion, Peloponnese, scale bar equals $1 \mathrm{~mm}$

consisting of Peloponnese population and $V$. ventrosa from GenBank was 0.013; mean distance between the above two groups equaled 0.055 .

In a maximum likelihood tree (Fig. 19), the four COI sequences from Milos form a clade with the ones of $V$. pontieuxini and $V$. maritima from the GenBank, and all four sequences from Peloponnese form a clade with the one of $V$. ventrosa from GenBank, with bootstrap support 100 .

Table 1. Pairwise p-distances between the studied COI sequences

\begin{tabular}{|c|c|c|c|c|c|c|c|c|c|c|}
\hline & 1 & 2 & 3 & 4 & 5 & 6 & 7 & 8 & 9 & 10 \\
\hline 1 AY616139 V. maritima & & & & & & & & & & \\
\hline 2 AF253077 V. pontieuxini & 0.0181 & & & & & & & & & \\
\hline 3 KJ406197 Milos & 0.0060 & 0.0121 & & & & & & & & \\
\hline 4 KJ406198 Milos & 0.0060 & 0.0121 & 0.0000 & & & & & & & \\
\hline 5 KJ406199 Milos & 0.0045 & 0.0136 & 0.0015 & 0.0015 & & & & & & \\
\hline 6 KJ406200 Milos & 0.0060 & 0.0121 & 0.0000 & 0.0000 & 0.0015 & & & & & \\
\hline 7 AF118357 $V$. ventrosa & 0.0498 & 0.0528 & 0.0468 & 0.0468 & 0.0452 & 0.0468 & & & & \\
\hline 8 KJ406201 Peloponnese & 0.0618 & 0.0618 & 0.0588 & 0.0588 & 0.0573 & 0.0588 & 0.0211 & & & \\
\hline 9 KJ406202 Peloponnese & 0.0498 & 0.0588 & 0.0468 & 0.0468 & 0.0452 & 0.0468 & 0.0121 & 0.0151 & & \\
\hline 10 KJ406203 Peloponnese & 0.0603 & 0.0633 & 0.0573 & 0.0573 & 0.0558 & 0.0573 & 0.0226 & 0.0045 & 0.0136 & \\
\hline 11 KJ406204 Peloponnese & 0.0618 & 0.0618 & 0.0588 & 0.0588 & 0.0573 & 0.0588 & 0.0211 & 0.0000 & 0.0151 & 0.0045 \\
\hline
\end{tabular}




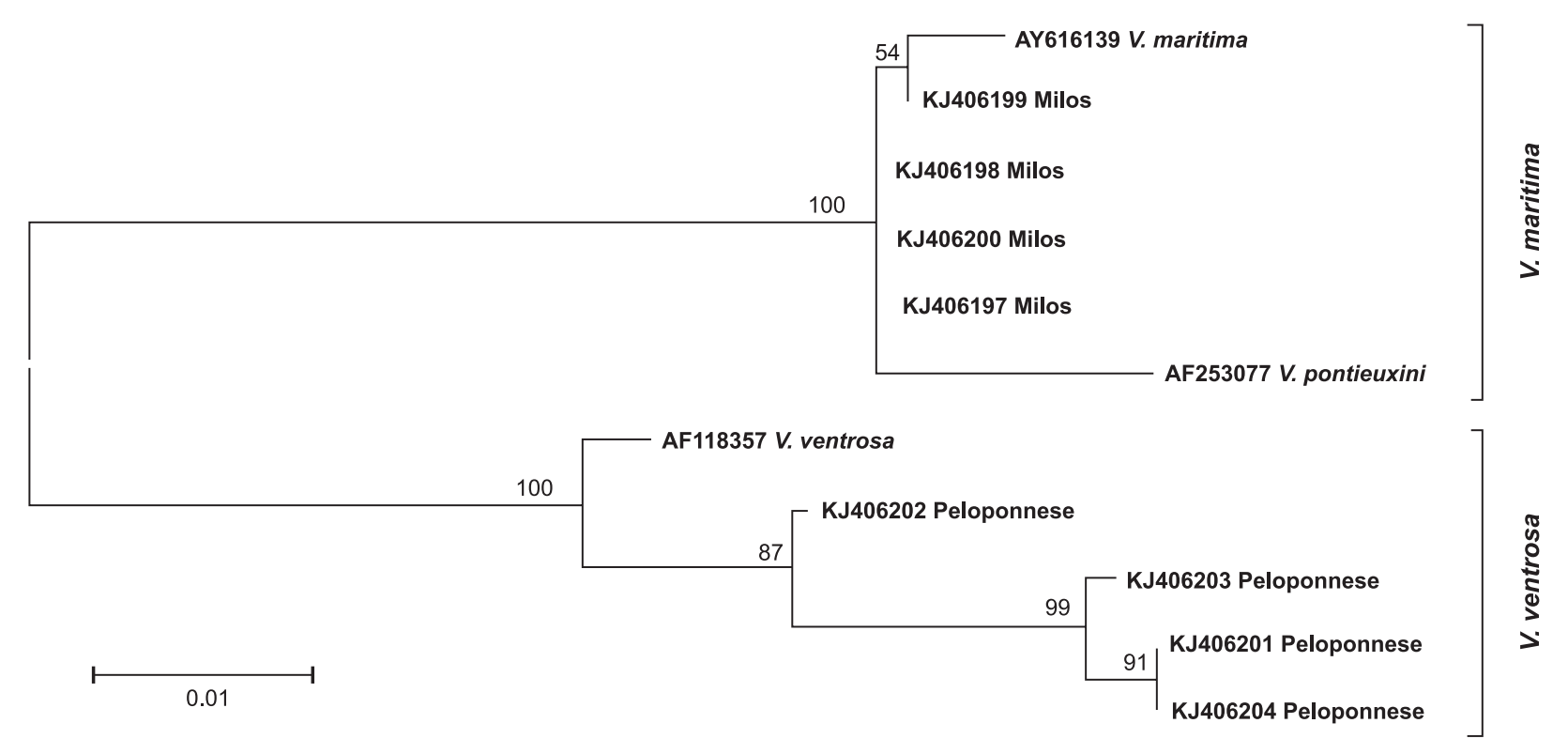

Fig. 19. Maximum likelihood tree based on COI, bootstrap supports given

\section{DISCUSSION}

As could be seen in the photographs (Figs 4-18), shell variability of the two species overlaps, and species determination based on the shell characters is impossible.

Both p-distances, and the ML tree support the species assignment of the Milos populations to $V$. maritima, and the ones from Peloponnese to $V$. ventrosa. $100 \%$ bootstrap support, coupled with the level of intergroup p-distances, support species distinctness of $V$. maritima, sometimes questioned. The sequence of $V$. maritima from the Black Sea ("V. pontieuxini" in Fig. 19) differs more from the ones from Milos than the sequence from the Evros Delta, which confirms isolation by distance pattern of genetic differentiation in Ventrosia. Genetic differentiation within $V$. ventrosa is higher than within $V$. maritima, which could be expected in such a widely distributed species (e.g. FALNIOWSKI 1987), but the intrapopulation diversity in the Peloponnese population was also high - somewhat higher than the one within all the specimens of $V$. maritima studied so far.

RADOMAN (1983) reports $V$. ventrosa from the Adriatic Sea. BANK (2012) does not report this spe- cies from Greece. To our knowledge, our study is the first molecularly confirmed report of the occurrence of $V$. ventrosa in this part of the Mediterranean Sea. RADOMAN (1973) described a new species $V$. pontieuxini, postulating species-level distinctness of the Black Sea Ventrosia, formerly classified as $V$. ventrosa. Later, V. pontieuxini Radoman, 1973 was considered a synonym of $V$. maritima (Milaschewitsch, 1916). As mentioned in the Introduction, KEVREKIDIS et al. (2005) found this species at the Evros Delta lagoons at the border of Greece and Turkey, East Aegean Sea. Thus, our finding expands the range of this presumably Pontic species $470 \mathrm{~km} \mathrm{SSW}$ in the Aegean Sea. Last but not least, our study confirms that molecular data are very useful for information on the distribution and species ranges within the brackish water Hydrobiinae.

\section{ACKNOWLEDGEMENTS}

The study was supported by a grant from the National Science Centre (2011/01/B/NZ8/01721) to ANDRZEJ FALNIOWSKI.

\section{REFERENCES}

BANK R. A. 2012. Fauna Europaea: Mollusca, Gastropoda. Fauna Europaea version 2.5. Available from: http:// www.faunaeur.org.

DAVIS G. M. 1992. Evolution of prosobranch snails transmitting Asian Schistosoma: coevolution with Schistosoma: a review. Prog. Clin. Parasitol. 3: 145-204.
DAVIS G. M., WILKE T., SPOLSKY C., QIU C.-P., QIu D.-C., XIA M.-Y., ZHANG Y., ROSENBERG G. 1998. Cytochrome oxidase I-based phylogenetic relationships among the Pomatiopsidae, Hydrobiidae, Rissoidae and Truncatelidae (Gastropoda: Caenogastropoda: Rissoacea). Malacologia 40: 251-266. 
Evagelopoulos A., Spyrakos E., Koutsoubas D. 2009. Phytoplankton and macrofauna in the low salinity ponds of a productive solar saltworks: spatial variability of community structure and its major abiotic determinants. Global NEST J. 11: 64-72.

FALNIOWSKI A. 1986. Pigmentation in Hydrobia ulvae (Pennant, 1777) and $H$. ventrosa (Montagu, 1803) (Hydrobiidae, Prosobranchia) from the Polish Baltic. Acta Hydrobiol. 28: 443-449.

FALNIOWSKI A. 1987. Hydrobioidea of Poland (Prosobranchia: Gastropoda). Folia Malacol. 1: 1-122.

FALNIOWSKI A. 1988. Female reproductive organs of Hydrobia ulvae (Pennant, 1777) and $H$. ventrosa (Montagu, 1803) from Puck Bay (Southern Baltic Sea) (Gastropoda, Prosobranchia, Hydrobioidea). Malak. Abh. 13: 27-31.

FELSENSTEIN J. 1985. Confidence limits on phylogenies: an approach using the bootstrap. Evolution 39: 783-791. http://dx.doi.org/10.2307/2408678

Folmer O., Black M., HoeH W., Lutz R. A., VRijenhoeK R. C. 1994. DNA primers for amplification of mitochondrial cytochrome $\mathrm{c}$ oxidase subunit I from diverse metazoan invertebrates. Mol. Mar. Biol. Biotechnol. 3: 294-299.

GITTENBERGER E. 1991. What about non-adaptive radiation? Biol. J. Linn. Soc. 43: 263-272. http://dx.doi. org/10.1111/j.1095-8312.1991.tb00598.x

HALL T. A. 1999. BioEdit: a user-friendly biological sequence alignment editor and analysis program for Windows 95/98/NT. Nucleic Acids Symp. Ser. 41: 9598.

Hillis D. M., MABLE B. K., LARSON A., DAVIS S. K., ZimMER E. A. 1996. Nucleic acids IV: sequencing and cloning. In: HiLlis D. M., MORITZ C., MABLE B. K. (eds). Molecular systematics. 2 ed. Sinauer Associates Inc., Sunderland, Massachusetts, pp. 321-381.

KEVREKIDIS T., WiLKE T., MOGIAS A. 2005. When DNA puts ecological works back on the right track: genetic assessment and distribution patterns of mudsnail populations in the Evros Delta lagoons. Arch. Hydrobiol. 162: 1935. http://dx.doi.org/10.1127/0003-9136/2005/01620019

Koutsoubas D., ARvanitidis C., Dounas C., Drummond L. 2000. Community structure and dynamics of the Molluscan fauna in a Mediterranean lagoon (Gialova lagoon, SW Greece). Belg. J. Zoology 130: 131-138.

MilaschewITSCH K. O. 1916. Mollyuski Chernogo i Azovoskogo Moryei. Fauna Rossii i sopredelnykh stran. Vol. I, Izd. Akademia Nauk, Petrograd.

MuUs B. J. 1963. Some Danish Hydrobiidae with the description of a new species Hydrobia neglecta. Proc. Malac. Soc. Lond. 35: 131-138.
MuUs B. J. 1967. The fauna of Danish estuaries and lagoons. Medd. Danm. Fisk. Hav. N. S. 5: 1-316.

PALUMBI S. R. 1996. Nucleic acids II: the polymerase chain reaction. In: Hillis D. M., MORITZ C., MABle B. K. (eds). Molecular Systematics. 2 ed. Sinauer Associates Inc., Sunderland, Massachusetts, pp. 205-247.

PANTAZIDOU A., LOUVROU I., ECONOMOU-AMILli A. 2006. Euendolithic shell-boring cyanobacteria and chlorophytes from the saline lagoon Ahivadolimni on Milos Island, Greece. Eur. J. Phycol. 41: 189-200. http://dx. doi.org/10.1080/09670260600649420

RADOMAN P. 1973. New classification of fresh and brackish water Prosobranchia from the Balkans and Asia Minor. Posebna Izdanja, Prirodn. Mus. Beograd 32: 1-30.

RADOMAN P. 1983. Hydrobioidea a superfamily of Prosobranchia (Gastropoda). I Systematics. Serbian Academy of Sciences and Arts, Monographs 547, Department of Sciences 57: 1-256.

SCHÜTT H. 1980. Zur Kenntnis griechischer Hydrobiiden. Arch. Moll. 110: 115-149.

Tamura K., Peterson D., Peterson N., Stecher G., Nei M., KUMAR S. 2011. MEGA5: Molecular evolutionary genetics analysis using maximum likelihood, evolutionary distance, and maximum parsimony method. Mol. Biol. Evol. 28: 2731-2739. http://dx.doi.org/10.1093/ molbev/msr121

WiLkE T., DAVIS G. M. 2000. Infraspecific mitochondrial sequence diversity in Hydrobia ulvae and Hydrobia ventrosa (Hydrobiidae: Rissoacea: Gastropoda): Do their different life histories affect biogeographic patterns and gene flow? Biol. J. Linn. Soc. 70: 89-105. http://dx.doi. org/10.1111/j.1095-8312.2000.tb00202.x

Wilke T., DAVis G. M., FALNiOWSKi A., GiUsti F., BOdON M., SzAROWSKA M. 2001. Molecular systematics of Hydrobiidae (Gastropoda: Rissooidea): testing monophyly and phylogenetic relationships. Proc. Acad. Nat. Sci. Philadelphia 151: 1-21. http://dx.doi. org/10.1635/0097-3157(2001)151 [0001:MSOHMG] 2.0.CO;2

Wilke T., FALNIOWSKI A. 2001. The genus Adriohydrobia (Hydrobiidae: Gastropoda): polytypic species or polymorphic populations? J. Zool. Syst. Evol. Res. 39: 227-234. http://dx.doi.org/10.1046/j.1439-0469.2001.00171.x

WiLKE T., PfENNINGER M. 2002. Separating historic events from recurrent processes in cryptic species: phylogeography of mud snails (Hydrobia spp.). Mol. Ecol. 11: 1439-1451. http://dx.doi.org/10.1046/j.1365294X.2002.01541.x

Received: December 3rd, 2013

Revised: January 21st/27th, 2014

Accepted: January 28th, 2014

Published on-line: March 5th, 2014 